\title{
Atmospheric depression as the final trigger for the seaward migration of the Japanese eel Anguilla japonica
}

\author{
Akihiro Okamura*, Yoshiaki Yamada, Satoru Tanaka, Noriyuki Horie, \\ Tomoko Utoh, Naomi Mikawa, Atsushi Akazawa, Hideo P. Oka
}

IRAGO Institute, 377 Ehima-shinden, Atsumi, Aichi 441-3605, Japan

\begin{abstract}
Despite the absence of rainfall or of any rise in river water level, the seaward migration of Japanese silver eels frequently occurs after the passage of a 'dry depression', suggesting that the migratory behavior of the eels is influenced by the atmospheric depression rather than by rainfall or elevated water level, as is usually thought. Our analyses showed that seaward migration of silver eels takes place mainly during the new moon in autumn to winter as water temperature decreases, suggesting the possibility that their migratory behavior depends on at least 3 independent environmental factors: water temperature, lunar phase and the passage of an atmospheric depression. However, water temperature and lunar phase were insufficient to cause the eels to start their migration. The passage of a depression was required as the final event to begin the seaward migration. These findings strongly suggest that the passage of a depression may be the only trigger that begins the seaward migration of silver eels.
\end{abstract}

KEY WORDS: Anguilla japonica - Silver eel $\cdot$ Atmospheric depression $\cdot$ Lunar cycle $\cdot$ Water temperature $\cdot$ Seaward migration

\section{INTRODUCTION}

Freshwater eels (genus Anguilla) are believed to migrate down the river to the sea on stormy nights (Deelder 1954). They are generally thought to be catadromous, spending the growth phase (5 or more years) in freshwater, after which sufficiently grown adults (silver eels) start to travel thousands of kilometers to their oceanic spawning grounds (Bertin 1956). For instance, Atlantic eels, Anguilla anguilla (European eel) and A. rostrata (American eel), are believed to spawn in the Sargasso Sea (Schmidt 1922), and the Pacific eel A. japonica (Japanese eel) spawns in the west of Mariana Island (Tsukamoto 1992).

Numerous researchers suggest that the onset of the spawning migration of the eels is affected by various in-

*E-mail: aokamura@irago.co.jp trinsic and extrinsic factors. Intrinsic factors such as sufficient age and sexual maturity are thought to be prerequisite for the onset of eel migration (Cairns 1941, Bertin 1956), and this migratory behavior is apparently controlled by several extrinsic (environmental) factors such as weather (Deelder 1954, Burnet 1969, Westin \& Nyman 1979, Hividstein 1985, Pursiainen \& Tulonen 1986, Vøllestad et al. 1986). In temperate species, including the Atlantic (Anguilla anguilla and A. rostorata) and New Zealand (A. australis and A. dieffenbachi) eels, decreasing water temperature is an important factor for the onset of migration because the downstream run is mainly observed in autumn to winter when water temperature decreases (Cairns 1941, Burnet 1969, Westin \& Nyman 1979, Todd 1981, Hividstein 1985, Pursiainen \& Tulonen 1986, Vøllestad et al. 1986, Haro 1991). Lunar periodicity is also important because the eels are most active during the last quarter of the lunar phase (Deelder 1954, Hividstein 1985, Pursiainen \& 
Tulonen 1986). Several studies showed that larger runs of silver eels were frequently observed in more severe weather and have suggested that the silver eel runs might be influenced by 3 related factors: rainfall, increased water level, and the passage of a depression (Burnet 1969, Todd 1981). However, which factor is most significant in affecting the eel runs is still not clear. At present, it is thought that these environmental factors may act concurrently on the eels' migratory behavior (Burnet 1969, Todd 1981).

In the present study, we attempted to assess the relationship between various environmental factors and the migratory behavior of silver eels, using the Japanese eel, with particular focus on 3 independent factors: water temperature, lunar phase, and atmospheric pressure. In this paper, we use 2 distinct terms with regard to their migratory behavior: 'downstream migration' when the eels swim from upstream to the river mouth, and 'seaward migration' when the eels move from the river mouth to the sea.

\section{MATERIALS AND METHODS}

Locality. The field study was carried out in Mikawa Bay $\left(34^{\circ} \mathrm{N}, 137^{\circ} \mathrm{E}\right)$ (Fig. 1), Aichi Prefecture, central Japan, during April 1997 to March 2000. Mikawa Bay has an area of about $200 \mathrm{~km}^{2}$ with mean depth of about $12 \mathrm{~m}$. The bay has about 20 inflowing streams, including 2 large rivers (the Toyo and Yahagi), and joins the Pacific Ocean through the Irago Channel.

Sampling. The sampling of eels was carried out by setnets, which were set along the coast of the Atsumi Peninsula (Fig. 1). A total of 25 nets were set at depths of 3 to 10 and 50 to $100 \mathrm{~m}$ from each shore. Sampling was undertaken every morning by 9 fishermen during the study.

Environmental parameters. Daily mean data on atmospheric pressure and rainfall observed at the Irago Weather Station (Fig. 1) near the sampling area were obtained from the Annual Report of the Japan Meteorological Agency (Anonymous 1997-2000a). Daily mean data on seawater (SW) temperature in Mikawa Bay, recorded by an automatic observational buoy (set at $3.5 \mathrm{~m}$ depth) (Fig. 1), were obtained from Aichi Fisheries Research Institute. Monthly data on river water (RW) temperature and daily mean data of water level in the Toyo and Yahagi Rivers, observed at about $30 \mathrm{~km}$ upstream from their mouths, were obtained from the Yearbook of Japanese Waters (Anonymous 1997-2000b). Because the patterns of fluctuation in the 2 rivers were similar, we used the data on the Toyo River as representative for both rivers in the following analyses.

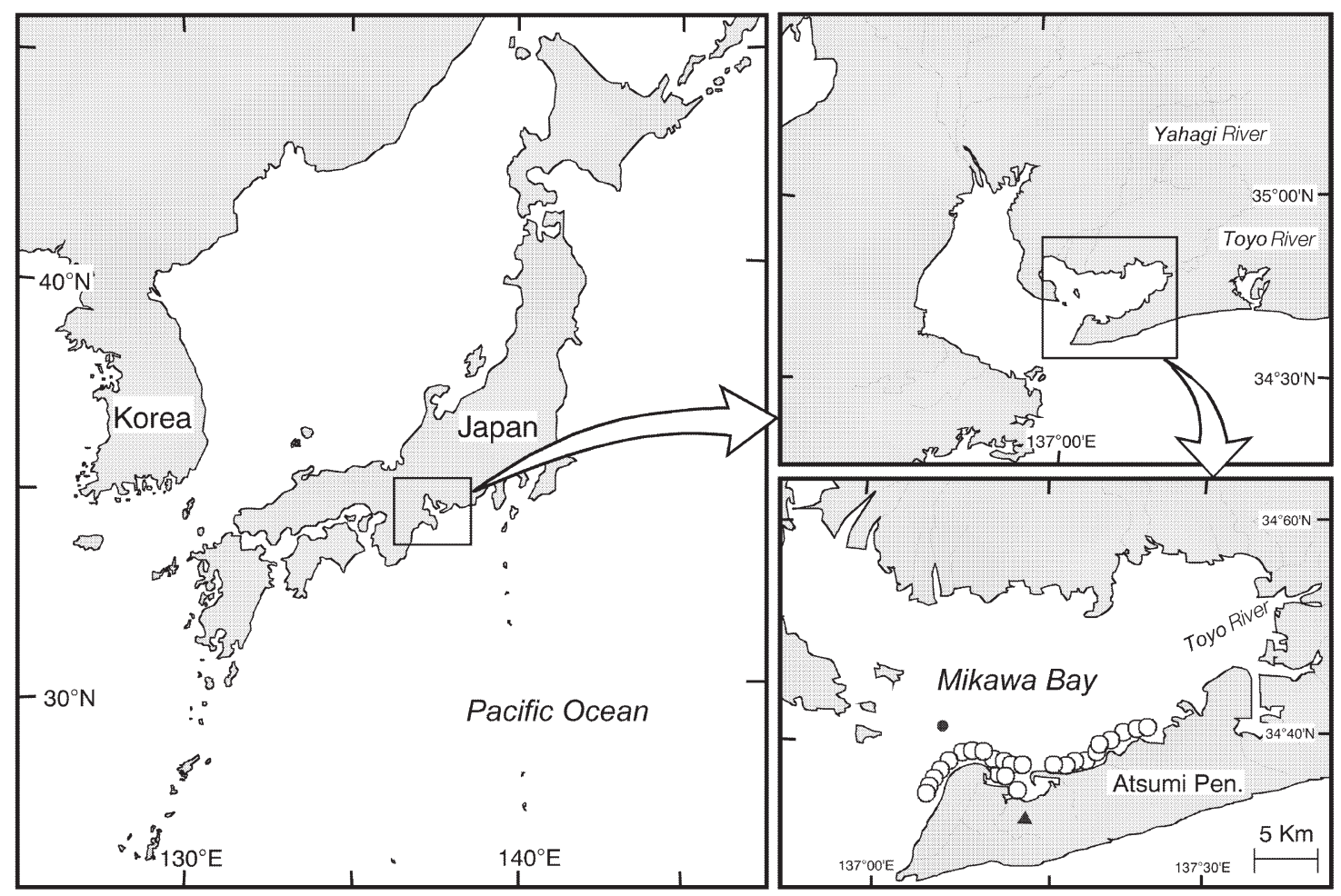

Fig. 1. Map of study area in Mikawa Bay, central Japan. o: setnets used to capture eels; $\bullet$ : the automatic observational buoy for measuring water temperature. $\mathbf{\Delta}$ : the Irago Weather Station 
The environmental parameters can be classified into 3 groups as follows: (1) long-term periodic factors, composed of SW (Mikawa Bay) and RW (Toyo River), which fluctuate seasonally; (2) a mid-term periodic factor, the lunar cycle, which has a 29.5 d periodicity; and (3) shortterm periodic factors, composed of atmospheric pressure, rainfall and water level of the river, all of which fluctuate daily. In the Mikawa area, the water temperatures do not show noticeable daily fluctuation.

In addition to these environmental parameters, we also analyzed the daily and monthly salinity and dissolved oxygen data in Mikawa Bay (from the Aichi Fisheries Research Institute). However, these data did not show any marked correlation with the eel catches. Thus, we will not describe these points in the 'Results' section.

\section{RESULTS}

\section{Eels}

A total of 1507 Japanese eels were caught. The mean total length (TL) of the eels was $69.5 \mathrm{~cm}$ (range: 37.0 to $100.8 \mathrm{~cm}$ ) and the mean body weight (BW) was $526 \mathrm{~g}$ (range: 94 to $1889 \mathrm{~g}$ ). Based on the dissection of 140 eels (9.3\% of the total), females were estimated to comprise $93.6 \%$ of the population. It is likely that the bias of this sex ratio is caused by the mesh size (larger inner mesh length: $30 \mathrm{~mm}$ ) used in the setnets, through which smallsized males are usually able to pass. The mean gonadosomatic index (GSI; gonad weight $\times \mathrm{BW}^{-1} \times 100$ ) of the females was 1.76 (range: 0.1 to 3.9). Eels collected from early spring to late summer (April to September) were small and apparently young $(<50 \mathrm{~cm}$ in TL) and their GSIs were relatively low $(<1)$, indicating that they were in the yellow phase (yellow eels). Almost all eels collected from autumn to winter (October to January) were relatively large (>50 $\mathrm{cm}$ in TL); their GSIs were relatively high (>1) and their skins displayed a silver color, indicating that they were in the silver phase (silver eels).

Apart from 1507 Japanese eels, 95 adventive European eels have also been caught in this area as previously reported (Zhang et al. 1999, Okamura et al. 2001). However, these European eels are not included in the following analyses.

\section{Patterns of catch}

There were at least 3 patterns in the fluctuations of eel catches each year: (1) seasonal fluctuations: this was the annual pattern, in which few eels were caught during spring to late summer, whereas many eels were caught during autumn to winter (Fig. 2); (2) monthly fluctuations: this pattern was repeated with a periodicity of about $30 \mathrm{~d}$ (Figs. 3 \& 4); (3) fluctuations over a few days: this was a pattern repeated after several days; a surge in catches frequently occurred every few days during autumn to winter (Figs. 3, 5 \& 6).

\section{Long-term periodic factors - water temperatures}

The monthly catch of eels increased during October to November each year, showed a peak in December, and decreased rapidly in January (Fig. 2). These fluctuations seemed to be associated with alterations of the water temperatures of both RW and SW. When the monthly RW temperature decreased to $<13^{\circ} \mathrm{C}$, the catches gradually increased. Maximum catches occurred when the RW temperature was $<10^{\circ} \mathrm{C}$. The catches decreased again when the RW temperature became $<5^{\circ} \mathrm{C}$. Similarly, when the monthly SW temperature decreased to around $20^{\circ} \mathrm{C}$, the catches gradu-

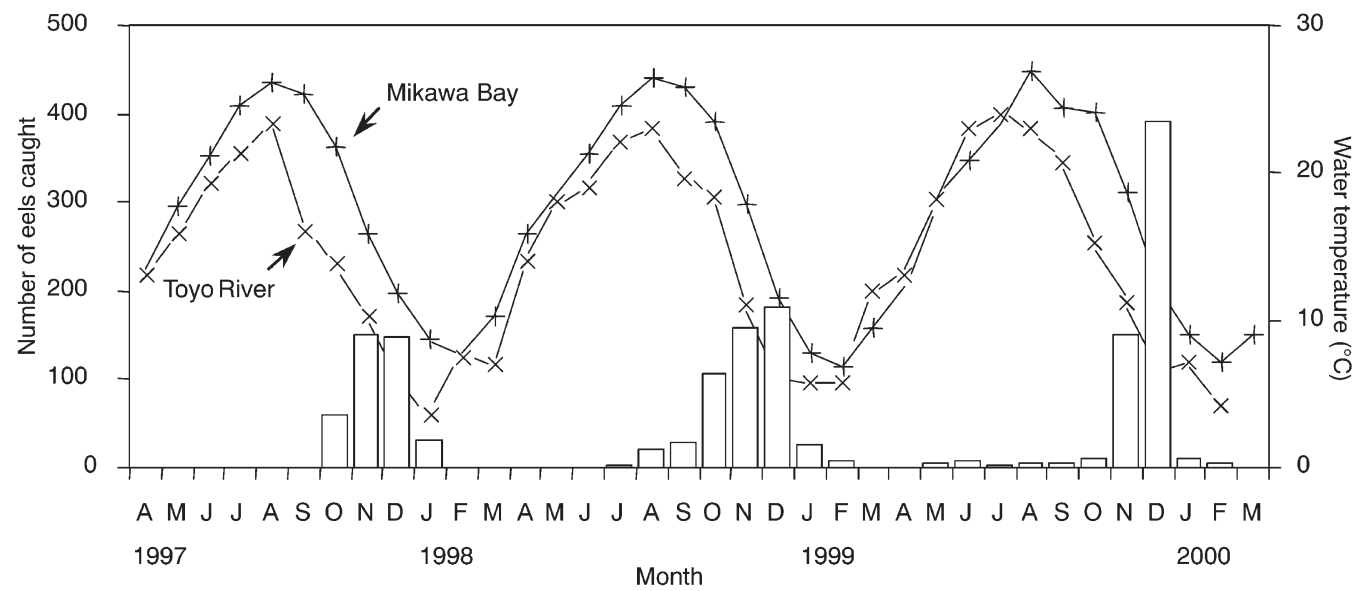

Fig. 2. Anguilla japonica. Monthly catch of migrating eels in Mikawa Bay and monthly mean temperature of the Toyo River (river water) and Mikawa Bay (seawater), April 1997 to March 2000 


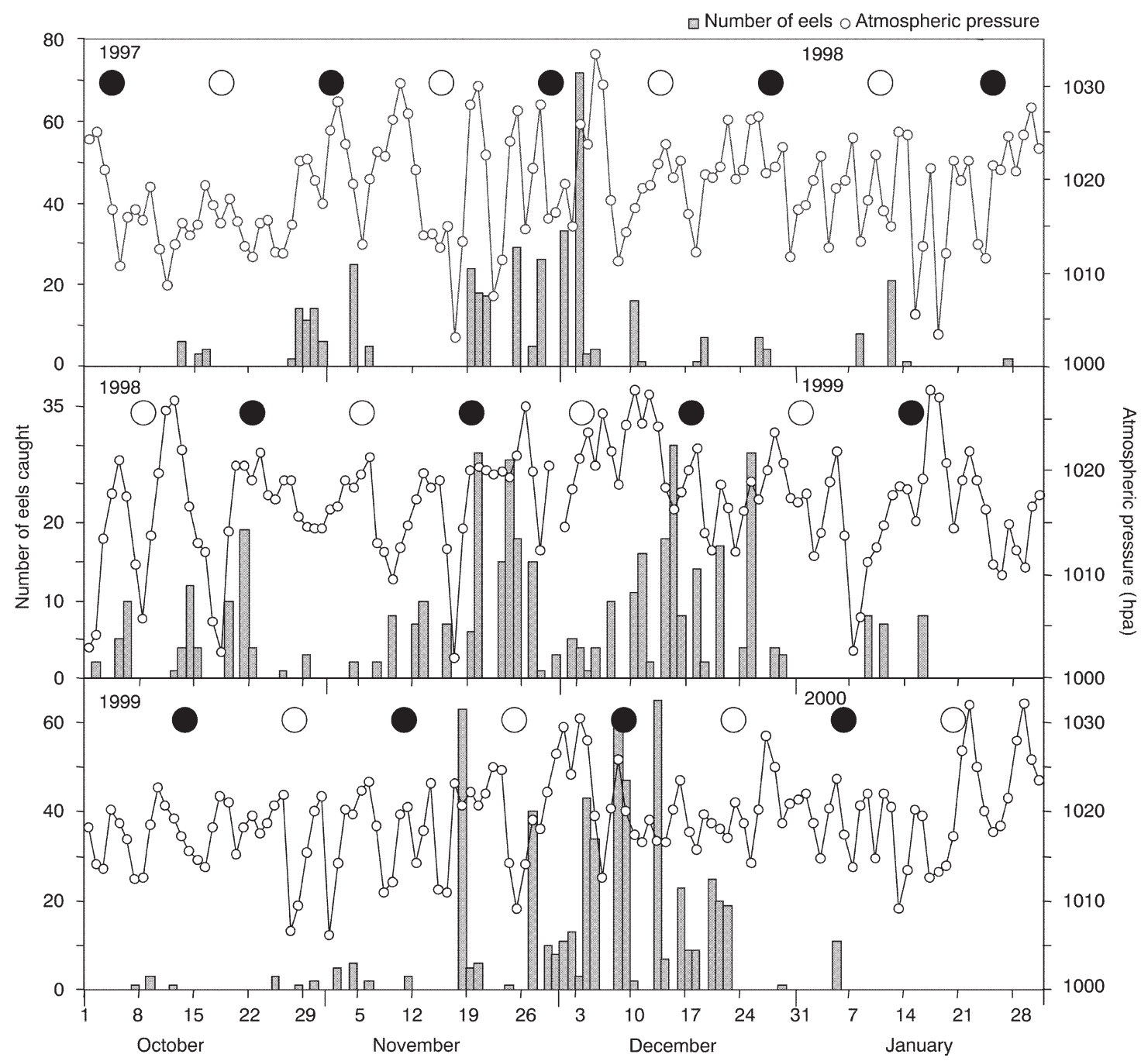

Fig. 3. Anguilla japonica. Daily catch of migrating eels in Mikawa Bay, changes in daily mean air pressure in the bay area, and lunar phase during October to January 1997 to 2000 (@: new moon; O: full moon)

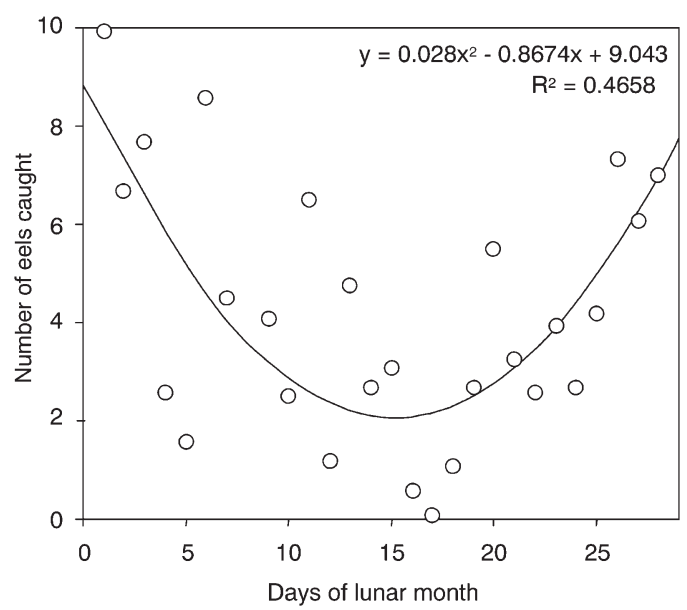

Fig. 4. Anguilla japonica. Average catch of migrating eels per day of lunar month during October to January 1997 to 2000 ally increased. Maximum catches occurred when the SW temperature was $\sim 13$ to $14^{\circ} \mathrm{C}$. Catches decreased again when the SW temperature was $<10^{\circ} \mathrm{C}$.

\section{Mid-term periodic factor - lunar cycle}

During October to January each year, the number of silver eels caught seemed to fluctuate with a roughly $30 \mathrm{~d}$ periodicity (Fig. 3). The peak catches seemed to almost coincide with the new moon, and catches were relatively small during the full moon. This is shown clearly in the average catch per day of lunar month during October to January over a period of 3 yr (Fig. 4). Maximum catches were made around the new moon, and minimum catches around the full moon. No eel was ever caught on Day 17 of the lunar cycle during the 3 yr (Fig. 4). 


\section{Short-term periodic factors - atmospheric pressure, rainfall and water level}

Atmospheric pressure

The daily catches seemed to fluctuate largely with a periodicity of a few days, in response to changes in air pressure (Fig. 3). In most cases, when an atmospheric depression passed through the bay area, large numbers of silver eels were caught within the following 2 or $3 \mathrm{~d}$. This fact is also shown in the frequency of catches in the days after the passage of a depression (Fig. 5). This clearly indicates that the peak catch occurred on Day 2 following the depression and over $70 \%$ of the catches occurred within the following $3 \mathrm{~d}$. Approximately 9 surges in catches (more than about 10 eels $\mathrm{d}^{-1}$ ), associated with depressions occurred during August to January each year (Fig. 3). For typical examples, when large depressions passed through the bay area on 17 November 1997, 17 November 1998 and 16 November 1999, there was a surge in catches as expected 2 or 3 d afterwards on each occasion (Fig. 3).

\section{Rainfall and water level}

Usually, the passage of a depression is accompanied by rainfall. However, the depressions passing through the bay area during autumn to winter were not always accompanied by rainfall (Fig. 6). There were exceptionally heavy rainfalls on 26 to 29 November 1997, 16 October 1998, 4 December 1998 and 1 November 1999, when the water level of the river rapidly rose to a level 2 to 5 times its normal height (Fig. 6). On other days, although a depression passed, there was little or no rainfall and no marked change in the water level of the river. In the 26 to 29 November 1997 and 16 October 1998 events, the catch of silver eels seemed to increase following the rise in water level (Fig. 6). However, particularly during 10 to 31 November 1998, despite no rainfall and no change in water level, large numbers of silver eels were frequently caught after the passage of a depression (Fig. 6).

\section{DISCUSSION}

\section{Three different patterns of catch}

Our analyses clearly showed that there were at least 3 patterns in the fluctuations of catches each year: seasonal fluctuations (Fig. 2), monthly fluctuations (Figs. 3 $\& 4$ ), and fluctuations over a few days (Figs. 3 \& 5). Interestingly, each type of fluctuation apparently coincided with the periodicities of the 3 groups of environ- mental parameters. The seasonal fluctuations coincided with those of both RW and SW temperatures as the long-term periodic factors. The monthly fluctuations coincided with those of the lunar phase as the mid-term periodic factor. The fluctuations over periods of a few days seemed to coincide with those of air pressure as the short-term pseriodic factor. These findings strongly suggest that the migratory behavior of eels is controlled by at least 3 independent periodic factors.

\section{Water temperature}

Silver eels were mainly caught during autumn to winter, which is in accordance with the results of previous studies that found the migration of silver eels to be closely associated with decreasing water temperature (Burnet 1969, Westin \& Nyman 1979, Todd 1981, Hividstein 1985, Pursiainen \& Tulonen 1986, Vøllestad et al. 1986). In most previous reports, it was assumed that RW temperature is more important than SW temperature for the downstream migration of silver eels, because they commonly live in the freshwater habitat before migration. In fact, many authors have focused on river or lake water temperature as an important factor affecting eel migration (Deelder 1954, Burnet 1969, Todd 1981, Hividstein 1985, Pursiainen \& Tulonen 1986, Vøllestad et al. 1986).

However, we suggest the possibility that SW temperature is as important as RW temperature for the migratory behavior of silver eels. To explain this, we hypothesize here that eel migration can be divided into 2 phases and that both RW and SW temperatures independently affect eel migration in the respective phases as follows. The first phase occurs when RW temperature decreases. The silver eels in the river start their 'downstream migration' to the river mouth and spend

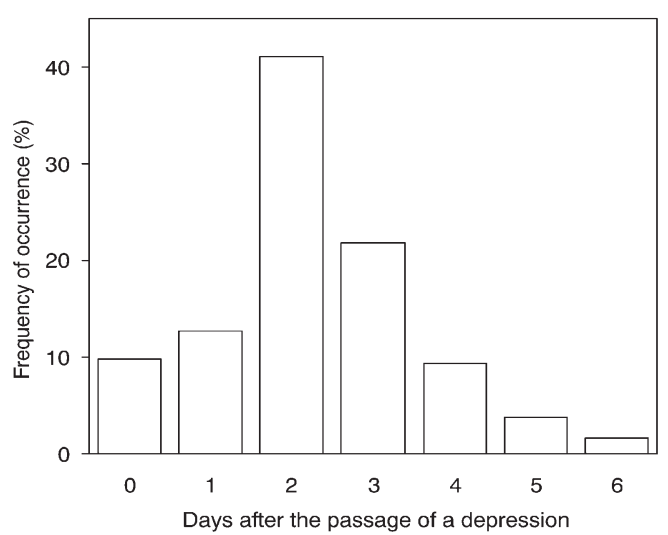

Fig. 5. Anguilla japonica. Frequency of occurrence of migrating eels in the days following the passage of an atmospheric depression during October to January 1998 to 2000 


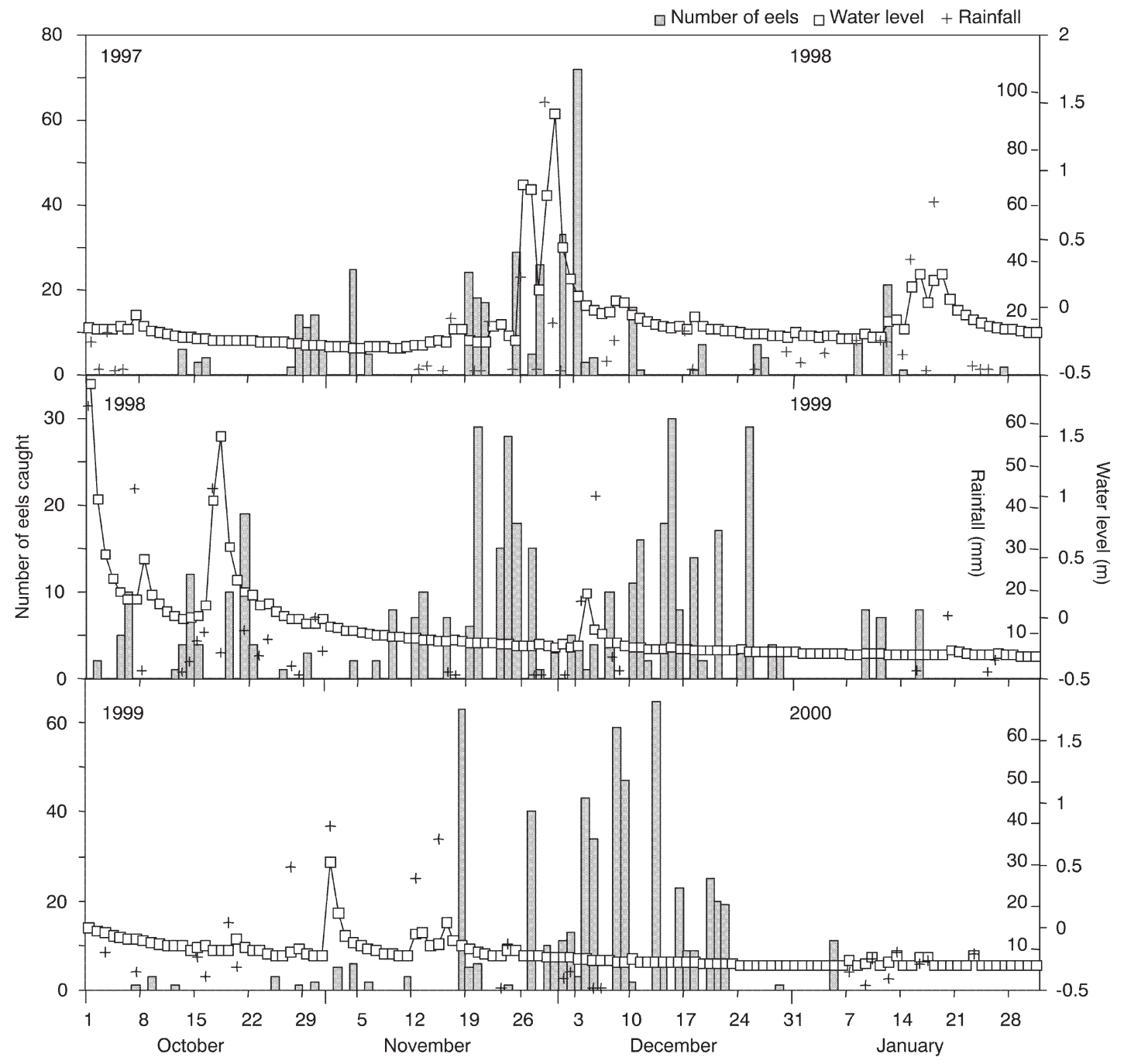

Fig. 6. Anguilla japonica. Daily catch of migrating eels in Mikawa Bay, changes in rainfall in the bay area and water level of the Toyo River during October to January 1997 to 2000

time in the estuary before entering the sea. When the eels reach the estuary during October to January, the SW temperature is 5 to $10^{\circ} \mathrm{C}$ higher than RW temperature (Fig. 2), suggesting that it may be difficult for the eels to pass through this area without stress. The second phase occurs when, after spending time near the river mouth, the silver eels become acclimated to the higher temperature and start the 'seaward migration' to the ocean. During this phase, it is possible that SW temperature affects the migratory behavior of silver eels.

A different version of a 2-phase migration was also hypothesized by Cairns (1941). He suggested that the eels usually remain in the estuary for some time before seaward migration, and during this period several changes take place in them: e.g. the eels stop feeding and the gut shrinks up, then the various parasitic worms which are present bore their way through the wall of the gut to the outside.

\section{Lunar phase}

Numerous studies have attempted to elucidate the relationship between the lunar phase and eel migrations. Several showed that the European silver eels often migrated during the last quarter of the lunar phase (Deelder 1954, Hividstein 1985, Pursiainen \& Tulonen 1986). However, our studies have shown that Japanese silver eels were more frequently caught during the new moon (Fig. 4), indicating that they actively migrated in this phase. This lag in migration times between previous findings and ours (from the last quarter to new moon: about $7 \mathrm{~d}$ ) can be explained by the difference in their study loci. Most previous studies were carried out in rivers (Deelder 1954, Burnet 1969, Todd 1981, Hividstein 1985, Pursiainen \& Tulonen 1986, Vøllestad et al. 1986); our studies were carried out in the sea. This distance could account for the time- 
lag. Furthermore, if the silver eels stay for some time in the estuary to acclimatize before entering the sea, this time-lag can easily be accounted for.

Although our data indicate that the migratory activity of silver eels in the sea is highest during the new moon, Boëtius (1967) found that, in laboratory experiments, the number of silver eels escaping from laboratory tanks apparently increased during the last quarter and decreased during the new moon. He suggested that escape activity reflected the natural migratory activity of silver eels. If so, our hypothesis indicates that such escape activity may reflect the activity of downstream migration rather than that of seaward migration. This further suggests that the lunar phase may play a role in the start of the downstream migration but not in that of the seaward migration.

\section{Atmospheric depression}

During the course of this study, despite the absence of rainfall or of any rise in water level, increased eel catches frequently occurred following the passage of depressions (Figs. 3, 5 \& 6), suggesting that the migratory behavior of silver eels, especially seaward migration, is influenced by depressions rather than rainfall or elevated water levels. In most previous studies, authors have suggested that migratory behavior, especially downstream migration, was associated with rainfall and elevated water levels. However, if the 2-phase migration hypothesis is true, silver eels carried downstream by water discharge do not enter the sea immediately, but stay at the river mouth for several days. After physiological acclimation to seawater, the silver eels may then start the seaward migration from the river mouth when a depression arrives.

In previous studies, several authors have also noted that a depression might be one of the most important factors for the migratory behavior of eels (Burnet 1969, Todd 1981). Nevertheless, it was not possible to determine which factor (elevated water levels, rainfall or atmospheric depressions) was most significant, because these meteorological phenomena commonly occurred simultaneously. In the present study in Mikawa Bay, fortunately, each environmental factor could be separated and analyzed independently by virtue of the passage of 'dry depressions', which were not accompanied by rainfall.

The increased eel catches frequently occurred within the following 2 or $3 \mathrm{~d}$ (Fig. 5). This is also accounted for by the following calculation. The distance between the main rivers (the Toyo and Yahagi) and the setnets is about 15 to $30 \mathrm{~km}$. According to several reports, eels swim horizontally at about 0.4 to $2.9 \mathrm{~km} \mathrm{~h}^{-1}$ on average in the sea (Westin \& Nyman 1979, Tesch 1989, Aoyama et al. 1999). If the eels move linearly to the nets from the river mouths, they will reach there within about 5 to $37 \mathrm{~h}$. Assuming that the eels do not move directly toward the nets, it is most likely that they will arrive after 2 or $3 \mathrm{~d}$.

\section{Model for the beginning of spawning migration}

Altogether, our results indicate that the migratory behavior of eels is controlled by at least 3 independent periodic factors - water temperature, lunar phase, and the passage of a depression. This finding further suggests that these factors independently affect the eels' behavior during different phases. Water temperature and the lunar cycle may mainly have an effect on the eels during downstream migration, whereas the depression may affect them during seaward migration. In fact, seaward migration of the eels was often observed during times of decreasing water temperature and the new moon. However, these 2 factors are not alone sufficient to allow the silver eels to start migration to the sea. In addition to these 2 factors, the passage of a depression as the final event is also required to allow them to start the seaward migration.

We suggest here a model for the beginning of spawning migration, which can be divided into 3 stages in addition to the 2-phase migration. First, certain physiological conditions, e.g. sufficient age, growth and sexual maturity, are fulfilled (Cairns 1941, Bertin 1956). Second, environmental conditions, water temperature and lunar phase reach their optimum and the eels move to the river mouth. Finally, a depression triggers the seaward migration.

The eels undergo various physiological changes before entering the sea. For instance, histological observations of the pituitary of silver eels show that a great abundance of secretory cells of a thyroid-stimulating hormone is present, possibly suggesting that this thyroid hormone may be related to migratory behavior (Knowles \& Vollrath 1966). This event and other physiological changes have so far been considered to be examples of the triggers for seaward migration. However, we think that these intrinsic events may be considered to be prerequisite physiological conditions (Stage 1) rather than triggers. Water temperature and lunar phase have also been considered to be the triggers for seaward migration. However, these 2 factors show a periodicity which is too large and too slow to be considered as triggers. Thus, it is reasonable to suggest that they represent environmental conditions (Stage 2) rather than triggers. The periodicity of alterations in air pressure is shorter than those of water temperature and the lunar phase and coincides well with the occurrence of large migrations of silver eels. Therefore, we 
conclude that atmospheric depressions play the role of the trigger for the beginning of seaward migration of silver eels (Stage 3).

Acknowledgements. We thank 9 fishermen for their kind corroboration. This study is a contribution (No. 012) of the IRAGO Institute.

\section{LITERATURE CITED}

Anonymous (1997-2000a) Anual report of the Japan Meteorological Agency. Japan Meteorological Business Support Center, Tokyo

Anonymous (1997-2000b) Yearbook of Japanese waters. Ministry of Land, Infrastructure and Transport, Tokyo

Aoyama J, Hissmann K, Yoshinaga T, Sasai S, Uto T, Ueda H (1999) Swimming depth of migrating silver eels Anguilla japonica released at seamounts of the West Mariana Ridge, their estimated spawning sites. Mar Ecol Prog Ser 186:265-269

Bertin L (1956) Eels - a biological study. Cleaver-Hume Press, London

Boëtius J (1967) Experimental indication of lunar activity in European silver eels, Anguilla anguilla (L.). Medd Dan Fisk Havunders 6:1-6

Burnet AMR (1969) Migrating eels in a Canterbury River, New Zealand. N Z J Mar Freshw Res 3:230-244

Cairns D (1941) Life-history of the two species of New Zealand fresh-water eel. Part I. Taxonomy, age and growth, migration, and distribution. N Z J Sci Technol B23: $53 b-72 b$

Deelder CL (1954) Factors affecting the migration of the silver eel in Dutch inland waters. J Cons Perm Int Explor Mer 20: $177-185$

Haro AJ (1991) Thermal preferenda and behavior of Atlantic

Editorial responsibility: Otto Kinne (Editor),

Oldendorf/Luhe, Germany eels (genus Anguilla) in relation to their spawning migration. Environ Biol Fish 31:171-184

Hividstein NA (1985) Yield of silver eel and factors effecting downstream migration in the stream Imsa, Norway. Rep Inst Freshw Res (Drottningholm) 62:75-85

Knowles, F, Vollrath L (1966) Neurosecretory innervation of the pituitary of the eels Anguilla and Coger II. The structure and innervation of the pars distills at different stages of the life-cycle. Phil Trans R Soc Lond B 250:329-342

Okamura A, Zhang H, Yamada Y, Utoh T, Mikawa N, Horie N, Tanaka S, Motonobu T (2001) Identification of two eel species, Anguilla japonica and A. anguilla by discriminant function analysis. Nippon Suisan Gakkaishi 67:1056-1060

Pursiainen M, Tulonen J (1986) Eel escapement from small forest lakes. Vie Milieu 36:287-290

Schmidt J (1922) Breeding places of the eel. Phil Trans R Soc Lond B 211:179-208

Tesch FW (1989) Changes in swimming depth and direction of silver eels (Anguilla anguilla L.) from the continental shelf to the deep sea. Aquat Living Resour 2:9-20

Todd PR (1981) Timing and periodicity of migrating New Zealand freshwater eels (Anguilla spp.). N Z J Mar Freshw Res 15:225-235

Tsukamoto K (1992) Discovery of the spawning area for Japanese eel. Nature 356:789-791

Vøllestad LA, Jonsson B, Hvidsten NA, Næsje TF, Haraldstad $\varnothing$, Ruud-Hansen J (1986) Environmental factors regulating the seaward migration of European silver eel (Anguilla anguilla). Can J Fish Aquat Sci 43:1909-1916

Westin L, Nyman L (1979) Activity, orientation, and migration of Baltic eel (Anguilla anguilla L.). Rapp P-V Réun Cons Int Explor Mer 174:115-123

Zhang H, Mikawa N, Yamada Y, Horie N, Okamura A, Utoh T, Tanaka S, Motonobu T (1999) Foreign eel species in the natural waters of Japan detected by polymerase chain reaction of mitochondrial cytchrome b region. Fish Sci 65: $684-686$

Submitted: June 11, 2001; Accepted: November 15, 2001 Proofs received from author(s): April 29, 2002 